\title{
Aktivitas Seni Siswa SD: Responsi Terhadap Kegiatan Ekstrakurikuler Vokal di SD
}

\section{Fithri Meiliawati*}

Universitas Sultan Maulana Hasanuddin Banten, Serang, Indonesia

*Corresponding author: fithri.meiliawati@uinbanten.ac.id

\begin{abstract}
Elementary School art students' activities: students' response towards vocal extracurricular activities in this school is based on students' establishment and development on vocal coaching extracurricular activities. The focus of this activities which oriented to vocal coaching activities in Elementary School are six students using some treatment about good and proper vocalizing techniques. The method of this research is qualitative method. Descriptive evaluative study is used to describe the situation and condition the process of vocal technique coaching in the school. The result of this study shows that after the coaching process the students' vocal ability and knowledge are increasing and improving. The study concluded that with the vocal extracurricular activities, students can sing with the right vocal technique.
\end{abstract}

Keywords: extracurricular; students; vocal

\section{ABSTRAK}

Aktivitas seni siswa SD: Responsi Terhadap Kegiatan Ekstrakurikuler Vokal di SD ini dilatarbelangkangi oleh pembentukan dan pengembangan siswa yang dilakukan melalui kegiatan ekstrakurikuler vokal. Hal ini diorientasikan kepada pembelajaran vokal melalui pelatihan materi seni khususnya vokal di SD dengan sasaran yaitu enam orang siswa melalui beberapa treatment mengenai teknik vocal yang baik dan benar. Metode penelitian yang digunakan yaitu metode kualitatif melalui studi deskriptif-evaluatif akan digunakan dalam penggambaran situasional dan kondisional proses pelatihan teknik vokal yang berlangsung di SD tersebut. Hasil yang diperoleh setelah diberikan beberapa traetment vokal adanya peningkatan pengetahuan serta kualitas vokal pada siswa. Dengan demikian melalui kegiatan ekstrakurikuler vocal ini siswa dapat bernyanyi dengan benar sesuai dengan teknik vocal yang baik.

Kata Kunci: ekstrakurikuler; siswa; vokal

\section{Pendahuluan}

Sekolah merupakan salah satu tempat untuk menimba ilmu, didalamnya terdapat kegiatan belajar dan mengajar yang bertujuan untuk mengembangkan potensi diri dengan berbagai disiplin ilmu dalam bentuk pengajaran secara formal. Adapun syarat dalam penyelenggaraan lembaga pendidikan atau sekolah perlu adanya: guru, murid, program pendidikan, sarana dan prasarana yang disusun secara sistematis sehingga dapat menunjang dalam pembentukan dan pengembangan siswa. Pembentukan dan pengembangan siswa dapat dilakukan melalui kegiatan intrakurikuler dan ekstrakurikuler yang menjadi program unggulan disetiap sekolah. Di massa pandemic ini tidak mengurangi rasa antusias siswa dalam melaksanakan kegiatan yang sudah diprogramkan oleh sekolah salah satunya adalah kegiatan ektrakurikuler Kegiatan ekstrakurikuler yang ditawarkan dan difasilitasi sekolah bertujuan untuk mengembangkan potensi siswa dalam meningkatkan minat dan bakat yang dimiliki oleh siswa, khususnya vocal atau bernyanyi, karena kegiatan bernyanyi untuk anakanak merupakan salah satu kegiatan yang menyenangkan dan sangat penting bagi perkembangan musikalitasnya. Namun dalam hal ini, materi yang disampaikan berupa 
penyampaian lagu tanpa melakukan teknik vocal atau teknik vocalizing dengan benar. Maka dibutuhkan beberapa treatment untuk meningkatkan kualitas bernyanyi anak.

Pada dasarnya vocal merupakan bunyi yang tidak disertai hambatan pada alat bicara, semua vokal dihasilkan dengan bergetarnya pita suara. Di dalam bernyanyi membutuhkan suara atau vocal yang baik artinya tidak fals atau tepat nada. Ada beberapa teknik yang perlu diperhatikan diantaranya yaitu adalah pernafasan. Pengelolaan pernafasan ketika bernyanyi dibutuhkan teknik pernafasan yang baik dan benar, karena pernapasan merupakan salah satu bentuk dari teknik vokal yang sangat penting dan memiliki pengaruh yang sangat besar terutama untuk bernyanyi. Orang yang memiliki pernafasan yang buruk tidak bisa bersuara dengan baik. Sebaliknya orang yang bisa mengatur dan menguasai pernafasannya akan sanggup pula mengatur dan menguasai suaranya (Sukohardi, 2001). Pernapasan terjadi pada saat akan menarik napas, napas akan terlihat bergerak kedalam tubuh anda, turun menuju paru-paru keluar disekitar tengah tubuh adalah sesuatu yang alami dan merupakan hal yang di inginkan, hal tersebut telah didefinisi sebagai pemindahan organ-organ perut yang disebabkan oleh gerakan mendatar dari diafragma (Hestyono, 1997). Dalam bernyanyi, pernapasan tidak hanya memegang peranan dalam menciptakan suara, tetapi juga suasana yang dikehendaki dari suatu nyanyian. Pernapasan terdapat 3 bentuk pernapasan diantaranya adalah pernapasan bahu, pernapasan dada, dan pernapasan diafragma, untuk pernapasan ini sering disebut dengan pernapasan sekat rongga dada, yakni pernapasan yang mengambil/menarik kekuatan nafas untuk mengisi paru-paru dengan menyebabkan rongga perut atau diafragma, yang juga diikuti dengan mengembangkan tulang rusuk. Cara ini merupakan cara yang baik dalam melakukan pernapasan karena, akan menghasilkan nafas yang ringan, santai, dan memproduksi suara lebih baik. Untuk menunjang keberhasilan pernapasan diafragma adalah posisi tubuh yang baik (Pohan, 1994).

Proses pembentukan suara memerlukan waktu latihan yang sangat cukup untuk mendapatkan suara yang berkualitas. Proses terbentuknya suara adalah nafas, udara yang disisipkan, kemudian dihembuskan atau dikeluarkan denga ringan dan santai secar teratur melalui kerongkongan (Voschoir, 2007). Selain itu yang dapat perlu diperhatikan adalah artikuasi. artikulasi merupakan kemampuan dibidang ini yang erat kaitannya dengan perkembangan fonansi (melafalkan kata-kata awal yang dikenal dengan baik sebagai landasan utama dalam peningkatang kemampuan inteligens berbahasa). Ketika bernyanyi sikap badan, pembawaan lagu, phrasering, vibra dan penjiwaan sangat perlu diperhatikan dalam meningkatkan kualitas vokal yang baik dan benar. Hal ini yang mendasari perlu dilakukan kegiatan ekstrakurikuler vokal yang mengedepankan teknik bernyanyi dengan benar guna memfasilitasi siswa dalam mengembangan minat dan bakat seni vokal karena selama ini pembelajaran vokal hanya dilakukan pada saat jam mata pelajaran SBK dan itupun hanya pada saat materi musik.

\section{Metode Penelitian}

Metode penelitian ini menggunakan metode penelitian deskriptif dengan menggunakan paradigma kualitatif, karena metode ini dapat membantu mendapatkan informasi yang akurat mengenai data-data di lapangan, dan mempermudah mengolah kembali data yang telah diperoleh sehingga data yang dihasilkan dapat dipaparkan secara objektif. Penelitian kualitatif dituntut mampu mengorganisasikan semua teori yang dibaca. Landasan teori yang dituliskan 
dalam proposal penelitian lebih berfungsi untuk menunjukan seberapa jauh peneliti memahami teori dan memahami permasalahan yang diteliti walaupun permasalahan tersebut masih bersifat sementara. Peneliti kualitatif justru dutuntut untuk melakukan grounded research, yaitu menentukan posisi teori berdasarkan data yang diperoleh dilapangan atau situasi sosial (Sugiono, 2011).

Penelitian ini akan dilakukan dengan beberapa tahap, yaitu teknik pengumpulan data di lapangan seperti cara observasi tentang proses pembelajaran vokal yang dilakukan di SDN Cigabus pada siswa kelas 4 yang mengikuti kegiatan ekstrakurikuler, proses wawancara dilakukan kepada guru dan siswa yang mengikuti kegiatan ekstrakurikuler, proses dokumentasi dilakukan pada saat proses ektrakurikuler vokal, studi literatur untuk mendapatkan referensi mengenai teknik vokal dan dilanjutkan dengan menganalisis data yang telah diperoleh secara deskriptif, kemudian data diolah menjadi laporan penelitian.

Pada penelitian kualitatif, permasahan di awal penelitian belum jelas dan pasti, maka instrumen yang paling tepat adalah peneliti itu sendiri, setelah masalah sudah mulai jelas, maka dapat dikembangkan sebagai intrumen yang sederhana yang diharapkan dapat melengkapi data dan membandingkan dengan data yang ditemukan melalui observasi dan wawancara. Instrumen penelitian berupa: (1) Pedoman wawancara, (2) Observasi dan (3) Dokumentasi. Dari hasil data instrument yang telah diperoleh maka dilakukan pengolah data sehingga dapat menghasilkan data yang akurat.

\section{Hasil dan Pembahasan}

Secara umum, vokal merupakan suara manusia yang ditimbulkan atau dihasilkan getaran pita suara. Dalam pembelajarannya diperlukan beberpa tahapan seperti teknik pernafasan, teknik vokalisi dan penguasaan materi lagu yang disesuaikan dengan ambitus suara, hal ini yang dapat membantu untuk meningkatkan kualitas vokal yang baik

Langkah awal dilakukan treatment-treatment pertama tentang teknik pernafasan yang terdiri dari pernapasan dada, bahu dan pernapasan perut atau diaghfraghma. dilakukan 3 teknik pernafasan bertujuan untuk perbandingan dan pengetahuan menganai teknik pernafasan. Pada mulanya siswa di intruksikan untuk berdiri dengan posisi tegak dan menggunakan pernapasan dada. Kemudian memberikan arahan cara pengambilan napas yang baik dan benar, yaitu dengan posisi tegak dan menggunakan pernapasan perut yang bertujuan agar ketika menghirup udara yang masuk akan tersimpan di dalam rongga perut, sehingga saat bernyanyi tidak terengah-engah. Dalam teknik pernafasan yang baik adalah dengan melakukan teknik pernafasan perut atau diaghfraghma. Latihan pernapasan yang diberikan yaitu dengan menarik napas, tahan, kemudian keluarkan napas perlahan-lahan. Latihan ini dilakukan selama beberapa menit. Kemudian latihan pernapasan selanjutnya mengarahkan untuk menambahkan bunyi "ssss" saat mengeluarkan napas. Siswa berdiri dengan posisi tegak, hirup napas secara perlahan dari hidung, tahan napas sebentar dengan 3 hitungan kemudian keluarkan napas melalui mulut dengan suara "ssss" ditahan sekuatnya. Latihan pernapasan ini tidak hanya dengan 3 hitungan saja. Akan tetapi dengan hitungan tiga, empat, lima, enam, tujuh, dan delapan pada saat menahan napas.

Pada saat melakukan teknik pernapasan perut terlihat ada beberapa siswa yang sudah bisa melakukannya dengan cukup baik dan ada pula yang perlu bimbingan. kemudian 
melakukan humming dengan menggunakan nada Do re mi fa sol fa mi re do. Humming digambarkan sebagai berikut:

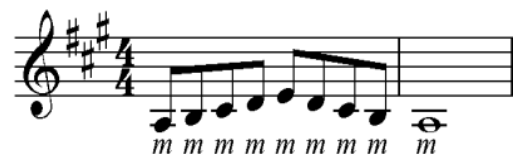

Gambar 1. Partiture Proses Humming

Materi vokalisi diantaranya membuka mulut lebar, vokal diucapkan dengan jelas, vokal diucapkan dengan mulut terbuka. Latihan pertama yaitu menarik napas lalu mengucapkan bunyi a dengan suara bulat. Siswa secara bergiliran mengucapkan bunyi a dengan bulat. Kemudian membunyikan huruf $i$, $u$, e dan o dengan bulat. Teknik vokalisi digambarkan sebagai berikut:
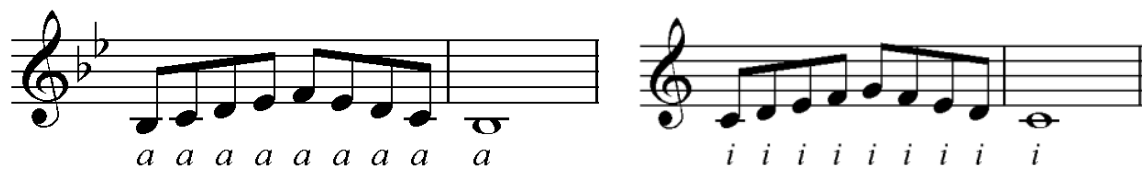

Gambar 2. Partitur Vocalizing

Kemudian menyanyikan lagu "Indonesia Pusaka". Melihat perkembangan bernyanyi siswa, masih terdapat beberapa kesalahan diantaranya belum sesuai dengan nada seperti pada lirik pertama pada kata "Indonesia". Digambarkan sebagai berikut:

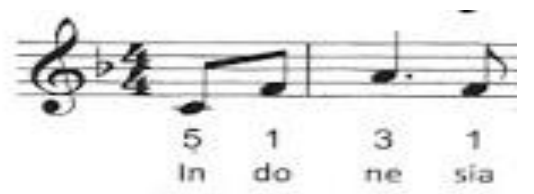

Gambar 3. Partitur Indonesia Pusaka

Kesalahan selanjutnya pada kata "Beta" dengan cara diayunkan. Digambarkan sebagai berikut:

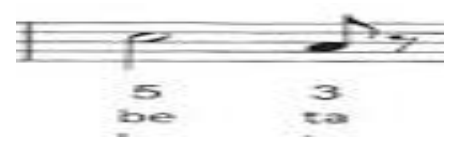

Gambar 4. Partitur Indonesia Pusaka

Treatment keempat yang diawali dengan teknik pernapasan dan dilanjutkan dengan materi vokalisi seperti yang dilakukan sebelumnya namun ada tambahan materi tentang tangga nada pada musik (Do re mi fa so la si do) ditambahkan dengan pengucapan A-I-U-E$\mathrm{O}$. 


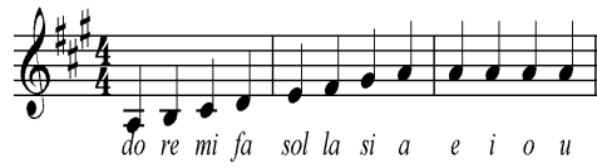

Gambar 5. Partitur Vocalizing

Tahap ini bertujuan untuk melatih pernapasan, karena pada step ini harus dinyanyikan dalam satu nafas, dan materi ini juga membantu untuk peningkatan ambitus suara karena menyanyikannya dengan meniti dari nada yang terendah sampai nada yang tertinggi. Pada mulanya pelatih mengenalkan tangga nada musik dengan alunan piano. Setiap siswa mendapat giliran untuk mengucapkan do re mi fa so la si do. Untuk melatih kepekaan terhadap tangga nada, siswa menyebutkan tangga nada dari nada rendah ke nada tinggi (Do re mi re do) atau yang di sebut dengan teknik vokalising. Setelah itu, secara bersamaan melakukan hal tersebut hingga pada akhirnya vokalising pertama dimulai dari nada A sampai nada g. Pada pertemuan ini, perkembangan siswa terlihat dari cara pengambilan napas dan ada beberapa siswa yang sudah dapat mengucapkan tangga nada dengan baik. Setelah itu dilanjutkan dengan menyanyikan lagu "Indonesia Pusaka".

Ttreatment sebelumnya yaitu tentang teknik vokalizing, namun pada treatment ke-5 ini mengucapkan tangga nada dari rendah ketinggi, rendah. lalu ke tinggi dan kembali lagi ke rendah ( do re mi fa sol fa mi re do sol do). setelah itu pelatih mengubah tangga nada tersebut dengan menggabungkan huruf konsonan dan huruf vokal, yaitu sebagai berikut:

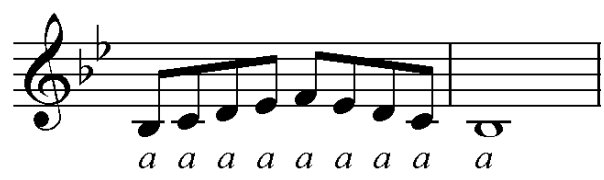

Gambar 6. Pertitur Vocalizing

Huruf- huruf konsonan tersebut bisa diganti dengan huruf konsonan yang lainnya, untuk pelatihan dirumah. Pada treatment ke-5 ini didapat teknik vokalisi kedua yaitu dari nada A sampai nadai f. Kemudian dilanjutan dengan bernyanyi lagu "Indonesia Pusaka". Perkembangan yang terlihat pada pertemuan ini adalah siswa sudah dapat mengatur napas mereka dalam bernyanyi lagu tersebut. Dan ada juga yang masih ada yang belum dapat mengatur napas dengan baik. treatment-treatment sebelumnya dengan bernyanyi. Yaitu menyanyikan lagu Indonesia Pusaka. Pertama mencontohkan menyanyikan lagu indonesia pusaka dan siswa-siswa memperhatikan kemudian menyanyikan lagu tersebut. Kemudian secara bergilir siswa menyanyikan lagu Indonesia Pusaka dengan alunan keyboard. Antusias dari siswa berbeda-beda saat diintruksikan untuk menyanyikan lagu tersebut. Ada yang percaya diri, ada yang semangat, ada yang malu-malu, ada yang gemetar, dan lain sebagainya. Namun perkembangan bernyanyi siswa sudah baik. Pada pertemuan ini kami lebih melihat perkembangan-perkembangan pada siswa yang sebelumnya sudah dibekali dengan beberapa treatment. Antusias siswa dalam pertemuan ini lebih meningkat daripada pertemuan-pertemuan sebelumnya karena ke enam siswa ini ditugaskan untuk berlatih di rumah untuk melancarkan dan melatih ekspresi ketika bernyanyi. Namun masih saja ada 
beberapa siswa yang belum sesuai dengan ketepatan nada dan kurangnya dalam berekspresi. Dan hal itu yang yang menjadi tugas peneliti dalam pertemuan ini. Untuk menghilangkan kebosanan kami pun mencoba bernyanyi dengan lagu-lagu lainnnya diantaranya ada lagu "ibu kita kartini, lagu untuk mama, garuda pancasila dan Andai aku punya sayap." Pada pertemuan terakhir anak sudah mulai bisa mengembangkan traetment sejak proses pertama. Ada kemunculan teknik terbaru yang belum diajarkan. Anak bisa mengembangkan kata perkata kalimat per kalimat menjadi penggalan-penggalan. Selain itu, siswa dapat bernyanyi dengan sempurna mulai dari penguasaan intonasi, ketepatan bunyi dan nada, artikulasi, penghayatan dan ekspresi.

\section{Kesimpulan}

Simpulan dari hasil penelitian mengenai "Aktivitas Seni Siswa SD: Responsi Terhadap Program Ekstrakurikuler Vokal" berdasarkan observasi dan eksplorasi adalah sebagai gambaran konkrit proses pembelajaran vocal di SD, dilakukan beberapa tahapan teknik vocal atau treatment yang dilakukan pada kegiatan ekstrakurikuler vokal yaitu: teknik pernafasan dilakukan dengan teknik pernafasan diaghfraghma atau perut, teknik vokalisi dan menyanyikan salah satu lagu wajib yaitu lagu "Indonesia Pusaka" serta pemahaman mengenai teknik vokal dan menyanyikan sebuah repertoar lagu yang awalnya belum sesuai dengan partitur, namun dengan diadakannya pemberian materi mengenai teknik vokal siswa jadi lebih tahu dan dapat mengikuti cara bernyanyi dengan baik.

\section{Daftar Pustaka}

Ali, M. (2006). Teknik-teknik Vokal. Bandung: Sinar Baru.

Ardiyani, R. S. (2017). Meningkatkan Kecerdasan Verbal-Linguistik Melalui Kegiatan Bernyanyi. Seminar Nasional PGPAUD UNTIRTA 2017 (p. 167). Serang: UNTIRTA.

Asih, Y. D. (2017). Metode Pembelajaran Vokal Untuk Anak-Anak Di Sanggar Nanin Music Course Kota Kediri. Jurnal Pendidikan Sendratasik, 1.

Banoe, P. (2003). Kamus Musik. Yogyakarta: Kanisius.

Hanna, S. M. (1998). Teori Musik Dasar. Yogyakarta: FPBS Ikip Yogayakarata .

Hestyono. (1997). Sekelumit Tentang Pengetahuan Paduan Suara. Bandung: UKIP.

Mukit, A. (2018). Implementasi Metode Bernyanyi dalam Mengenalkan Pendidikan Agama Islam Pada Anak Usia Dini: Studi Pada PAUD Al HasanahDesa Dempo Timur Pasean. Konferensi Integrasi Interkoneksi Islam dan Sains (p. 15). Sunan Kalijaga.

Pohan. (1994). Membentuk paduan suara. Bandung: Loka Karya Musik Gereja.

Pramayuda. (2010). Belajar Vokal Dasar dan Paduan Suara. Bandung: Alfabeta .

Priyatna, S. J. (2017). Pembelajaran Vokal Pada Pelajaran Seni Budaya Dan Keterampilan. Jurnal Pena Ilmiah, 1-13.

Putra, N. E. (2018). Pengaruh Ekstrakurikuler Terhadap Keaktifan Dan Hasil Belajar Matematika Siswa. Seminar Nasional Pendidikan Era Revolusi (p. 281). Jakarta: UMT.

Senen, S. (1983). Unsur-unsur Musik. Jakarta: Musikindo .

Sugiono. (2011). Metode Penelitian Pendidikan. Bandung : Alfabeta. 
Sukohardi. (2001). Teori Musik Umum. Yogyakarta : Pusat Musik Liturgi.

Voschoir. (2007). seni-adalah-ungkapan-perasaan-seseorang. Retrieved from cepspenza.blogspotcom: http://cepspenza.blogspotcom/2007/06/seni-adalahungkapan-perasaan-seseorang

Yuni, Q. F. (2016). Kreativitas Dalam Pembelajaran Seni Musik Di Sekolah Dasar: Suatu Tinjauan Konseptual. ELEMENTARY, 55. 